\title{
KENNETH LOACH'S RIFF-RAFF, BETWEEN THE BRITISH DOCUMENTARY TRADITION AND THE WORKING-CLASS CINEMA ${ }^{1}$
}

\author{
José Díaz Cuesta. Universidad de La Rioja
}

\begin{abstract}
Riff-Raff (1991) is analysed as a functional hinge between the British documentary movement of the twenties, the free cinema of the fifties and the present current of social films such as Trainspotting (1996), Brassed off (1996) or The Full Monty (1997). Kenneth Loach seems to have incorporated the theoretical doctrine of the British documentary tradition in most of his films, especially in Riff-Raff, as we can see in his way of dealing with scripts and actors. Simultaneously he has introduced what we may call the humour factor, widely used in the working-class films of the 1990s.
\end{abstract}

\section{INTRODUCTION}

In 1991, when Kenneth (usually known as Ken) Loach was the recipient of the Best European Film of the Year award for Riff-Raff, the jury was not only recognising a single film but a whole way of understanding cinema. A window was being opened to an apparently new trend in the history of British cinema. A number of what have been called social or workingclass films -which have the working classes as their subject matter- have been released after the appearance of that former film which in Britain was not only given very little distribution but also wrongly advertised. The reason for this sort of exclusion lies in Ken Loach's political standpoint as a representative of the Left in film-making. In spite of this lack of recognition in his own country, Loach's films of the 1990s were internationally acclaimed. In Spain, for instance, Riff-Raff was awarded the 'Espiga de Oro' in the 1991 Seminci of Valladolid. Similarly, the 1990s current of British working-class films like Trainspotting (1996), Brassed Off (1996) or The Full Monty (1997) owed a great deal to Kenneth Loach's films, especially to Riff-Raff. They were all fiction films which had people belonging to the working class as main characters, and some aspect of their lives as the subject matter of each.

The aim of this article is to show how Riff-Raff has functioned as a hinge between previous trends of realism in cinema and the more recent working-class films of the 1990s. For that

${ }^{1}$ This article is dedicated to the memory of Adolfo Cuesta who first introduced me to Riff-Raff. 
purpose we firstly account for the method followed by Ken Loach in Riff-Raff. Then we briefly look at the history of realism and the documentary in British cinema, aiming to look for traits which are present in Loach's recent film-making. Thirdly, we relate Riff-Raff to the current trend of social films. Eventually we conclude by showing how Riff-Raff has functioned as a catalyst between the realist tradition and those more modern social films.

\section{KEN LOACH'S METHOD IN RIFF-RAFF AND OTHER FILMS OF THE 1990S²}

Loach may have asked someone to write a script, but this used to happen after that person had sent him an idea. In Riff-Raff, both the idea and the script came from Bill Jesse, whose sense of humour Loach especially liked ${ }^{3}$.

For the casting Loach did not use the script but situations similar to those that would appear in the film. He preferred to use non-professional actors and actresses, although this was not completely possible since trade unions prohibited this practice. That is why many of the characters in his films were performed by people with some experience in the theatre or any other form of public performance (Fuller, 1998: 87). Occasionally he also worked with completely professional actors, like Carlyle in Carla's Song. Nevertheless Loach chose him for Riff-Raff because the actor had been working as a painter and decorator (Pérez, 1998: 18 and Fuller, 1998: 85). On the whole, Loach looked for people who had a background similar to that of the character they had to represent.

Loach shot chronologically: there is no need to mention the implications of this in budgetary terms. Loach did so because he wanted the people who incarnated the characters of his films to feel at the same time as the characters. For this reason he did not only shoot chronologically but also gave the script to the actor or actress on a daily basis: they did not know what was going to happen next in the story. As in the casting, situations (Fuller, 1998: 87) were preferred to scenes, that is, actors and actresses were expected to undergo an experience that led them to utter the words that were not present in the script they were using, which was not the complete script where dialogues appeared in full. Loach's system also included variations or surprises of which actors or actresses were not previously aware. In Riff-Raff Ricky Tomlinson did know that someone was going to enter the bathroom while he was naked, taking a shower, but he had not been told that instead of another man from the building site it would be a group of Muslim women that definitely took him by surprise.

When shooting Loach put the camera on the tripod and locked it off. By this I mean that he was not worried about complicated camera positions or shot-reverse shot relations. He preferred to leave an unobtrusive recording eye in the situation he had created or re-created. The same was applied to sound: he was never worried about someone talking at the same time as another person because, in his view, that was what usually happened in real life. If possible, Loach would choose actual settings for his films: Riff-Raff was shot on a real building site, and the dressing rooms used by the crew of the film were the same that the workers of the place had been using. When no real place could be utilised ${ }^{4}$ the newly designed set should also conform to the general rule of not being distracting for actors and actresses. Moreover the amount of

\footnotetext{
${ }^{2}$ In this section we mainly use Bollaín (1996), who was allowed to follow the crew of Carla's Song (1996). She compares her observations with her own experience in Land and Freedom (1994) and with previous experiences of other members of the crew in former films by Loach, including Riff-Raff.

${ }^{3}$ Jesse, to whom the film is dedicated, died before Riff-Raff was finished.

${ }^{4}$ Loach was facing the same kind of problem documentary makers may have. As Baddeley (1963: 56) comments, "There are times in documentary work when it is necessary to forsake the genuine background for a studio-built set."
}

Odisea, $\mathrm{n}^{0} 1,2001$ 
people whom actors and actresses in a situation could see would be reduced to the minimum, and, as a consequence, most of the crew had to keep out of sight as much as possible.

Once all the scenes or situations were shot, the postfilmic stage of editing took Loach longer than it is usual for most directors, since he used all the material he had shot, which, according to Bollaín (1996: 198) meant that for each take the ratio between choosable takes and the finally chosen one was 30:1. This fact was aggravated by Loach's preference for the traditional moviola instead of the much faster digital system.

Bollaín (1996: 85) asked the director whether this film-making system always works, to which he answered: "Siempre sale [...] porque tendrá el casting adecuado, la localización adecuada y se rodará en el momento adecuado. Y si sale otra cosa, y es sincera, es de verdad, será válida."

\section{FROM THE BRITISH DOCUMENTARY TRADITION TO KEN LOACH'S RIFF- RAFF}

For this analysis of the realist strand in British working-class cinema and its relevance to the 1990s films of Ken Loach, especially to Riff-Raff, we shall primarily follow two chapters of the book (1992) All Our Yesterdays: 90 Years of British Cinema, edited by Charles Barr. In the first of them Andrew Higson offers a diachronic approach to "the documentary-realist tradition" (72) and in the second Sylvia Harvey studies the evolution of the "'other cinema"" (225), mainly understood as "the voice (or voices) of the working class" from 1929 to 1984. On the whole, I think that both of them refer to the same thing, to what one may call working-class cinema. Here we shall trace the history of the British working-class cinema, trying to detect what echoes of this tradition are present in Riff-Raff.

The first wave of British documentaries was partly influenced by the French avant-garde strand of the 1920s (Higson, 1992: 75). Jean Vigo (1989: 138), commenting on a 1929 French documentary, writes that "el juego consciente no puede permitirse. El personaje deberá ser sorprendido por la cámara, de lo contrario hay que renunciar al valor «documento» de este tipo de cine." This stance, although in a different shape, was present in Riff-Raff, since his working method involved taking characters by surprise on a daily basis. In Britain this early strand was initiated by John Grierson with his film Drifters (1929). He was the founder and best exponent of what is known today as the British Documentary Movement. He (in Forsyth, 1979: 20) summarised his influences as follows:

What I know of cinema I have learned partly from the Russians, partly from the American westerns, and partly from Flaherty, of Nanook. The westerns give you some notion of the energies. The Russians give you the energies and the intimacies both. And Flaherty is a poet.

From the Russian cinema he took its editing style and its adoption of the working man as a hero (Swann, 1989: 32-33). He also admired the fact that the state would finance films of a higher level than the average commercial film. Of Flaherty he liked his ethnographic approach to film-making. In the westerns he discovered the importance of nature in its relation to characters and spectators. However he was absolutely opposed to commercial cinema, as he (in Hardy, 1979: 48) once wrote: "The dogs of the commercial world are harried and driven to quick box-office results." Grierson believed in the importance of the state for his conception of cinema, although not exactly like the Soviet model, as Aitken (1990: 192-3) has put it: 
Grierson's enthusiasm for the public corporation was also influenced by his conception of the State. He conceived of the State, not as one centralized unit, but as an amalgamation of relatively autonomous corporate entities, in which power was equally distributed.

One of those entities was the Empire Marketing Board, where Grierson led its Film Unit ${ }^{5}$. "In cinema we got the very brief commission 'to bring the Empire alive,"” he (in Hardy, 1979: 49) asserted. He thought that in spite of the propagandist nature of the task they were allowed a great deal of freedom (Hardy, 1979: 48). Each year, their documentaries were of three kinds: simple and inexpensive instructional films (How to Tie a Parcel, for instance), usually shown in schools; two or three prestigious and costly productions (for example Night Mail, in 1936, by Watt and Bright); and low-budget experiments, such as Lye's A Colour Box in 1936 (Swann, 1989: 66). Grierson pointed to the budget as one of the main reasons for his choice of the documentary, for the whole of their production was really cheap if compared to any fiction film (Hardy, 1979: 50). Money was also involved in this decision, since Drifters was relatively successful (Swann, 1989, 35), especially if compared to Creighton's feature film One Family (1930), also produced by the $\mathrm{EMB}^{6}$. Grierson delimited three main principles (Hardy, 1979: 3637): firstly, that documentaries should explore live scenes in a real world; secondly, that people who represent themselves were preferred to professional actors; and thirdly, that the materials and narratives chosen in this way would be better, more real, than those found in a studio with professionals. For Grierson (1933: 8), a documentary should aim at "the creative interpretation of actuality." As seen in the previous section, these principles -especially the last two ones-are clearly manifest in Loach's filming method in Riff-Raff, where all the actors at the building site had some professional background in the construction field.

The Documentary Movement also went through an independent period in the 1930s, making socially-concerned documentaries sponsored by the private sector and following, in this way, Flaherty's financing model in Nanook. These films managed to show working-class problems at the same time as they were a propagandist banner of companies such as the gas industry (Swann, 1989: 95-122). Swann concludes that the problem with Grierson and his followers in the 1930s was that theirs were films by an élite for an élite (1989: 178). Nevertheless they will always be important for having introduced the working class on the cinema screen, as Grierson recalls (in Sussex, 1975: 1): "I was very interested in this question of putting the working class on the screen."

The 1930s also saw the appearance of the workers' film movement. It was the time of organizations like the Workers' Film Society, the Workers' Film and Photo League, the Progressive Film Institute and Kino. Some of their members belonged to the Labour Party and many to the Communist Party, which meant that they represented a working-class opposition to the government (Harvey, 1992: 234). They not only coincide with Loach in this last point but also in their financial problems and their intention of influencing people by means of their films. Most of their production belongs to the documentary genre, although it is possible to find fiction films.

\footnotetext{
${ }^{5}$ The same team would follow him when, after the abolishment of the EMB, Tallents, his superior civil servant, made his own appointment conditional on keeping the whole group together (Swan, 1989: 47; Aitken, 1990: 3).

${ }^{6}$ Paradoxically, the commercial success of Grierson's film favoured the adoption of the documentary by the EMB.
}

Odisea, $n^{o} 1,2001$ 
During the Second World War, according to Higson (1992: 84), "it is clear that the story documentary and the narrative fiction film are converging, both in terms of the aesthetic devices and strategies used, and in terms of the personnel involved." Film-makers as famous in fiction film as Carol Reed and David Lean direct documentaries about the war, but, as Higson (1992: 84) puts it, "Harry Watt's films for the GPO [General Post Office] and Crown Film Units are perhaps the key examples of the story documentary tendency." Their films are very close to Loach's approach to his characters. Higson (1992: 85) recalls that:

These films also try to hold together two different forms of characterisation: on the one hand, the stereotyping, or typage (another Soviet influence) of the documentary film - that is, the casting of non-professional actors who bear a physical resemblance to the social type to be represented; and on the other hand, the psychological realism of the narrative fiction film - that is, the progressive inscription of character with the marks of a unique individuality.

The next important movement is the Free Cinema of the late 50 s and early 60 s, which started in February 1956 with the presentation of four short films at the National Film Theatre (Romaguera and Alsina, 1989: 253). Their aesthetics and attitude were mainly influenced by the Angry Young Men (Dixon and Dupin, 2001: 28-29). This group of film-makers also had the documentary movement as a key reference, but from a critical standpoint, since they rebel both against the trivialization of the fiction film and the financial support of documentaries by the government. Loach realized the first of these rebellions from the start of his career, but not until the 1990s did he understand that if his films were not to be censored he should have to leave the BBC. Free Cinema film-makers criticized the fact that film characters were not allowed to talk with a regional accent, something about which Loach is very much concerned and which forced Riff-Raff to be shown with subtitles in America.

Since then there were other movements with the working classes as their main themes. Among them we should remember the Modern Independent Movement, from 1966 to 1979, together with the London Film-makers' Co-operative, created in 1966, and the Independent Film-makers' Association (IFA), founded in 1974. Although they looked back at the workers' movement of the $30 \mathrm{~s}$, they were far from the realist tradition and hence far from Loach's working method in his films of the 1990s.

The same happened with the rise of independent films in the $1980 \mathrm{~s}$, some of them developed by marginalized groups like women and black people, whose voice had not been heard before (Harvey, 1992: 244). According to Harvey (1992: 243-44):

The two most important factors for the development of independent film in the 80s have been, at the political level, the break with consensus and the major right-wing offensive initiated by the Thatcher governments of 1979 and 1983; and, at the economic level, the advent of Channel Four Television and the appointment (as a result of a long and intensive campaign by the Independent Film-makers' Association) of a Commissioning Editor with responsibility for funding independent film.

In Riff-Raff Loach coincided with these films only at the political and the economic levels, by strongly criticising Thatcher's policy and by being sponsored by Channel Four.

After this historical overview we can observe that many of the theoretical and practical notions of realist and documentary working-class films were still present in Riff-Raff. 
Loach does not like to acknowledge their influence ${ }^{7}$, and perhaps he is right in doing so, since similar movements which may have consciously influenced his work can be found across Europe ${ }^{8}$. For that reason we prefer to understand the relationship between Loach's 1990s work and previous British realist working-class films in terms of precedence in time rather than conscious influence. Those films had appeared in Britain before and they conditioned the cinema to come by the creation of a tradition in film-making from which it is very difficult to set Loach's films aside. Loach must have seen some of those films, which were already influenced by other European and American cinemas, and which created a tradition in British film-making. It is as if the documentary and realist traditions in the working-class British cinema had behaved with Loach in the same way as he did with actors and actresses, without having complete access to a script that nevertheless he followed in the end.

\section{KEN LOACH, RIFF-RAFF AND THE WORKING-CLASS FILMS OF THE 1990S}

The influence of Ken Loach's films on a whole generation of younger film-makers is much more overtly recognized than the influence that previous strands of realist and documentary cinema had had on Loach's work. Alan Parker (in Hacker and Price, 1990: 273), for instance, had already dedared in a 1986 interview that Cathy Come Home was "the single most important reason why I wanted to become a film director." By the same time, Roland Joffé (in Hacker and Price, 1990: 273) also pondered on this film: "The first time that I saw Cathy Come Home I was ravished because there were "people". This is a man who allows people to be. I wanted to embrace everything that Ken stood for." More recently Christopher Eccleston (1996: 8) has said that

Ken Loach's 'Kes' is of great importance to me. It was the first picture I went to as a kid where I felt there was something resembling my own life on screen. [...] 'Kes' created an appetite for something else, and it inspired me to seek out the kind of work that it was possible to see on television in the 70s and early $80 \mathrm{~s}$.

Eccleston's words are really clarifying because they reflect how once someone has seen a film by Loach, there arouses an immediate interest for other films of the director and/or for works by other people also close to those represented and addressed to in Loach's films. The final consequence should be that they make films following Loach's approach, as is the case of the director Les Blair (1997: 61):

Seeing Saturday Night and Sunday Morning made me feel that there were stories I could tell. That it was OK to talk about the world you knew about. I got the same feeling later when I saw Loach's Cathy Come Home. It made me feel that this was the kind of films we should be making.

But all these people refer to films prior to the 1990s and therefore previous to Riff-Raff. Some may question that if all the 1990s films by Loach follow a similar pattern, why should Riff-Raff be given more importance than any of his previous works? On the one hand, Riff-Raff

\footnotetext{
${ }^{7} \mathrm{He}$ tends to link his films to European influences, as is the case of his usual cinematographer, Chris Menges, who had previoulsy worked with Ondriceck (De Giusti, 1999: 8).

${ }^{8}$ See Collas (1997) for a panoramic view of realist cinema across Europe.
}

Odisea, $n^{0} 1,2001$ 
has served as a valuable tool to show the rest of Loach's production to people who had not known about them, perhaps because of the international acclaim that the film received?. On the other, some of the different —although related— themes of Riff-Raff appear only on spec in the film. For an analysis of the various ways in which Riff-Raff is present in the last strand of social films, let us consider the three films mentioned at the beginning of this essay: Trainspotting, Brassed Off and The Full Monty.

Trainspotting (1996), directed by Danny Boyle, coincides with Riff-Raff at its thematic level, since its subject-matter is the world of drug addiction, a theme already included in Riff-Raff as the reason why the relationship between the two main characters is broken and also as one possible reason for Steve's moving to London. This is not the main theme in Loach's film, although the moment in which Steve tells Susan to leave is one of the crudest in the film, not only because this means the break-up of their love affair, but also because he reacts so strongly to Susan's problem due to the drug addiction of his own sister. The formal treatment given to this topic in Trainspotting is very different from RiffRaff, since here we find the use of low camera angles and a vivacity of colours and fantastic visual effects which are associated with the influence of drugs, something one would never find in Riff-Raff or any other film by Loach in the 1990s. Robbery is the other topic touched on in Riff-Raff which also appears in the second film, although in this latter case it eventually happens between people who are supposedly friends. The film, based on a 1993 novel by Irvine Welsh, follows the acid humour of the original rather than the softer tone of Loach's film. Yet there is another coincidence between both films in the actor Robert Carlyle, who nevertheless plays dissimilar roles in each of them.

Mark Herman's Brassed Off (1996) is closer to Riff-Raff in its main theme but the formal treatment given to it also differs from that of Loach's film. The opening sequence shows miners going out of a pit in a semi-documentary style: we see them at work and taking the necessary shower, and we get to know that the women are demonstrating "against pit closure." All this happens while we hear the music of a brass band which gives the sequence a more superficial tone than what the images let us imagine, a tone that is kept until the end, with the additional introduction of a love story and the dramatic episodes of the band conductor's illness. These devices, which are key elements for the plot, are here used very differently from Riff-Raff, where the love story and the accident suffered by a worker appear only incidentally, as happens in real life. Anyway, the problem of unemployment, one of the main themes in Riff-Raff, constitutes the main topic in Herman's film, where the politics of the Conservative party are overtly denounced. In Riff-Raff, apart from the film's general message, this denunciation is made patent by Larry when he harangues his mates at the building site, whereas in Brassed Off the device chosen is to show a message on screen ("SINCE 1984 THERE HAVE BEEN 140 PIT CLOSURES IN GREAT BRITAIN AT THE COST OF NEARLY A QUARTER OF A MILLION JOBS") while the band is playing through the streets of London.

Of the three films selected for our commentary, Peter Cattaneo's The Full Monty (1997) is the one that most closely resembles Riff-Raff. The film starts with a propagandist short documentary about Sheffield twenty five years before the main action takes place, in what seems to be not only a criticism on the splendid visions of the future (now present) announced there, but also a rejection of that sort of film, which gives an idealised and hence false view of the situation. Robert Carlyle again represents a primary character who is unemployed, like most of his friends, also former steelworkers. Unlike Riff-Raff, where reactions against the system can be seen in violent individual outbreaks, with the eventual collaboration between Carlyle and another of

${ }^{9}$ As Julian Petley (1992: 124) puts it, "tanto Hidden Agenda como Riff Raff han difundido la figura de Loach entre las nuevas y entusiastas audiencias extranjeras."

Odisea, $n^{0} 1,2001$ 
the workers in setting fire to the building site, The Full Monty proposes a re-grouping of exsteelworkers in order to collaborate with each other in the preparation of a striptease performance. Tomlinson had undergone a similar situation in the already discussed sequence of Riff-Raff, but again it was accidental and unintentional. The funniest thing is that some people were actually misled by the image of the naked worker in the bathroom, which was wrongly used (Petley, 1992: 156) in the promotion of Loach's film: they had to wait until the end of The Full Monty to see a group of strippers, though. The Full Monty is much richer than the mere physical and moral nakedness of its protagonists, since it also highlights the ongoing changes in the relations between men and women, something which was not at all included in Riff-Raff.

As for the way these three films were made, they all coincide, in opposition to Riff-Raff, in not following Loach's working method. All their actors and actresses had access to a detailed script, their shooting did not occur chronologically, the sound was carefully recorded and edited..., that is, they followed the conventional way of making feature films. Even The Full Monty, closer in the themes touched upon, as we have just seen, is far from Riff-Raff, as Simon Beaufoy (1998: 61), screenwriter of The Full Monty, asserts:

Though I love the naturalism of Riff-Raff, my writing moves towards moments that break free of these confines, that rise above the reality of the situation into something that no matter how earthy, one could call a sort of poetry. The scene in the dole queue in The Full Monty, where the laid-off steel workers, hearing familiar music, break into an involuntary strip-dance, for instance. You wouldn't find that in a Loach film because it breaks the bounds of pure naturalism.

It seems that the directors of these films looked at Loach's film focusing on the results of applying the method and preferring to choose more traditional ways in their approaches to characterization ${ }^{10}$. There is also coincidence in that in all four films we can hear characters talking with their local accents. Furthermore all of them are partially or totally sponsored by Channel Four Television, a trait now common to many British independent films. But perhaps the most important common factor is their use of humour, which also relates them to yet another tradition in the British cinema: the black humour of the Ealing comedies. Although, according to Loach (1998: 10), the reason for the humour in his films may lay on his choice of subject matter: "la gente con menos posesiones es la que tiene más sentido del humor." Nevertheless, there are differences in the use of humour between Loach and the other filmmakers, since his approach is sadder and more realistic, whereas the others' is lighter and less easy to believe (Hill, 1998: 18-19; Beaufoy, 1998: 61).

\section{CONCLUSION}

Riff-Raff was influenced by the British tradition in documentary and realist films which had the working class as their subject matter. Their influence may have been direct or indirect, but those films created an appetite in the audience for something else. In the 1990s that appetite was satisfied by working-class films like the exemplified Trainspotting, Brassed Off and The Full Monty. Riff-Raff functioned as a catalyst between the above mentioned tradition and the more modern social films, which were influenced by Loach's film mainly by dealing with issues which constitute the main themes of the three films mentioned, but even more importantly by allowing their directors and producers to realise that the working class could go back to the big screen as a subject matter.

${ }^{10}$ John Hill (1997: 138) also points at Mike Leigh as co-responsible for the revival of British realism.

Odisea, $\mathrm{n}^{0} 1,2001$ 
Hacker and Price (1990: 274-275) sum up Loach's intentions when making films:

First, he wants to give a voice to the working class, one which he feels is never heard. [...] Secondly, Loach wants to change society with his films. [...] Thirdly, in the process of doing this he also hopes to sustain the Left 'by letting them see their own ideas reflected back at them, which is something that very rarely happens in the media'.

Loach seems to have achieved at least the first and third of his intentions, as both aims have been amplified by the subsequent films of other directors. At the same time, although those directors do not follow Loach's method, they follow its results, behind which, as we have seen, there is a whole tradition of realist and documentary film-making with the working class as its subject matter, as well as a previous use of humour as exemplified by the Ealing comedies. In this way it can be concluded that Riff-Raff, for the national and international acclaim that it received, functioned as a hinge between the frame of a tradition in the documentary and a window which was being opened for a more modern way of understanding working-class cinema. ${ }^{11}$

\section{REFERENCES}

Aitken, I. 1990. Film and Reform. John Grierson and the Documentary Film Movement. London and New York: Routledge.

Baddeley, W.H. 1963. The Technique of Documentary Film Production. London and New York: Focal Press.

Barr, C. ed. 1992. All Our Yesterdays: 90 Years of British Cinema. London: BFI.

Beaufoy, S. 1998. "Hidden agendas". Sight and Sound 8, 3: 61.

Blair, L. 1997. "Northern exposure". Sight and Sound 7, 9: 6.

Bollaín, I. 1996. Ken Loach. Un Observador Solidario. Madrid: El País/Aguilar.

Boyle, D. dir. 1996. Trainspotting. United Kingdom: Figment Film with The Noel Gay Motion Picture for Channel Four Films.

Cattaneo, P. dir. 1997. The Full Monty. USA/United Kingdom: Redwave Films, developed by Channel Four Television Company for Twentieth Century Fox Film Corporation Fox Searchlight.

Collas, G. 1997. Cine Europeo. El Desafio de la Realidad. Valladolid: Semana Internacional de Cine de Valladolid.

Eccleston, C. 1996. “'Kes' and my own life”. Sight and Sound 10: 8.

De Giusti, L. 1999. Ken Loach. Bilbao: Ediciones Mensajero.

Dixon, B. and C. Dupin. 2001. "Soup dreams", Sight and Sound 3: 28-30.

Fuller, G. ed. 1998. Loach on Loach. London: Faber and Faber.

Grierson, J. 1933. "The documentary producer”, Cinema Quarterly 2, 1: 8. . 1992. "Postulados del documental”. Textos y Manifiestos del Cine. Eds. J. Romaguera i Ramió and H. Alsina Thevenet. Madrid: Cátedra. 139-147.

${ }^{11}$ I would like to thank Peter Evans for his comments on an earlier version of this essay. 
Hacker, J. and D. Price. 1990. Take 10: Contemporary British Film Directors. Oxford: Oxford University Press.

Hardy, F. ed. 1979. Grierson on Documentary. London \& Boston: Faber and Faber.

Harvey, S. 1992. "The 'other cinema' in Britain: Unfinished business in oppositional and independent film, 1929-1984". All Our Yesterdays: 90 Years of British Cinema. Ed. C. Barr. London: BFI. 225-251.

Herman, M. dir. 1996. Brassed Off. United Kingdom: Steve Abbott/Mark Herman/ Prominent Features for Channel Four Films.

Higson, A. 1992. “'Britain's outstanding contribution to the film': The documentaristrealist tradition". All Our Yesterdays: 90 Years of British Cinema. Ed. C. Barr. London: BFI. 72-97.

Hill, J. 1997. "Finding a form: politics and aesthetics in Fatherland, Hidden Agenda and Riff-Raff". Agent of Challenge and Defiance. The Films of Ken Loach. Ed. G. McKnight. Wiltshire: Flick Books. . 1998. "Every fuckin' choice stinks". Sight and Sound 8, 11: 18-21.

Loach, K. dir. 1965. Up the Junction. United Kingdom: BBC. . dir. 1966. Cathy Come Home. United Kingdom: BBC. . dir. 1969. Kes. United Kingdom: Woodfall/Kestrel Films. dir. 1990. Hidden Agenda. United Kingdom: Initial Film \& Television Production/Hendale. . dir. 1991. Riff-Raff. United Kingdom: Parallax Pictures for Channel Four. . dir. 1994. Land and Freedom. United Kingdom: Parallax Pictures, Messidor Films, Road Movies Dritte Produktionen.

dir. 1996. Carla's Song, United Kingdom/Spain: Parallax Pictures, Tornasol Films-Alta Films, Road Movies Dritte Produktionen, with the help of the Glasgow Film Fund, the Instituto de Cultura de Nicaragua, Ard Degeto Film, Filmstiftung Nordrehein-Westfalen and Televisión Española. . 1998. "Ken Loach, director de Mi nombre es Joe". Seminci 7: 100-11.

MacMurraugh-Kavanagh, M. K. 1997. “'Drama' into 'news': strategies of intervention in 'The Wednesday Play'”. Screen 38, 3: 247-259.

Petley, J. 1992. Ken Loach. La Mirada Radical. Valladolid: 37 Semana de Cine with the collaboration of The British Council.

Romaguera i Ramió, J. and H. Alsina Thevenet, eds. 1989. Textos y Manifiestos del Cine. Madrid: Cátedra.

Swan, P. 1989. The British Documentary Movement, 1926-1946. Cambridge: Cambridge University Press.

Vigo, J. 1992. "El punto de vista documental. «À propos de Nice» (1929)". Textos y Manifiestos del Cine. Eds. J. Romaguera i Ramió and H. Alsina Thevenet. Madrid: Cátedra. 134-138. 